\title{
HUBUNGAN PENGETAHUAN, SIKAP, DAN BUDAYA DENGAN PERILAKU PENGGUNAAN AIR SUNGAI (Studi Di Wilayah Kerja Puskesmas Martapura 2)
}

\author{
Sharah Monica Yunida \\ Departemen Promosi Kesehatan dan Ilmu Perilaku \\ Fakultas Kesehatan Masyarakat, Universitas Airlangga, \\ Alamat Korespondensi: Sharah Monica Yunida \\ Email: chicha.hammy@gmail.com
}

\begin{abstract}
Diarrhea is one of the most common infectious diseases. It has related three factors such ass environment, food and contact with an infected person. One of the environmental factor of diarrhea is the domestic water use behavior. The main objective of this study was to analyse the relation between knowledge, atitude and habit to domestic water use behavior in Martapura 2 Public Health Center, work area Pasayangan Selatan Village, subdistrict of Martapura, Banjar, South Kalimantan Province. Case control study design was used in this study. The population of the study were all diarrhea patients in Martapura 2 Public Health Center work area from february 2017 until february 2018. The Lemeshow was used to determine research sample size. The study sample consisted of 45 case diarrhea patients and 45 control non diarrhea patient. Samples were taken from all eligible cases and controls on specified inclusion and exclusion criteria. Data will analysed use Chi Square. Based on the results of this study comparing between case group and control group, most of the respondents in the case group have knowledge in poor knowledege was 25 people (55.6\%) and the control group in good knowledge that was 35 people (77.8) with Chi Square, all $p<0,001$. Attitudes of respondents in the case group were in the not good category is 26 people (58.0\%) and control group in good category that was 32 people $(71,1 \%)$ with ( $p$ value 0,000 in case and control 0,004). Utilitation habit respondents in the case group were in the non-existent category of 26 persons (57.8\%) and the control group in the category of no 37 people (82.2\%) with ( $p$ value in case 0.006 and control 0.000). Conclusively, the variable of knowledge, attitude and habit have very significant relation on the group of case and control.
\end{abstract}

Keyword: diarrhea, water use behavior, knowledge

\begin{abstract}
ABSTRAK
Salah satu penyakit menular yang paling sering terjadi adalah diare. Diare memiliki tiga faktor yang erat kaitannya dengan lingkungan, makanan serta kontak dengan orang yang terinfeksi. Salah satu faktor lingkungan penyebab diare adalah perilaku penggunaan air sungai. Tujuan umum penelitian ini adalah untuk menganalisis hubungan pengetahuan, sikap dan budaya terhadap perilaku penggunaan air sungai di wilayah kerja Puskesmas Martapura 2, studi di Desa Pasayangan Selatan Kecamatan Martapura Kabupaten Banjar, Provinsi Kalimantan Selatan. Penelitian ini menggunakan pendekatan kasus kontrol. Populasi penelitian adalah seluruh penderita diare di wilayah kerja Puskesmas Martapura 2 dari February 2017 sampai Februari 2018. Pengambilan sampel penelitian menggunakan rumus Lemeshow. Sampel penelitian terdiri dari 45 responden kasus diare dan 45 responden control bukan pasien diare. Sampel diambil dari semua yang memenuhi syarat kasus dan kontrol pada kriteria inklusi dan eksklusi yang telah ditetapkan. Analisis data menggunakan Chi Square. Berdasarkan hasil penelitian membandingkan antar kelompok kasus dan kontrol, sebagian besar responden pada kelompok kasus memiliki pengetahuan pada kategori tidak tahu yaitu 25 orang (55,6\%) dan kelompok kontrol pada kategori tahu yaitu 35 orang $(77,8)$ dengan $C h i$ Square, keduanya $p<0,01$. Sikap responden pada kelompok kasus berada pada kategori kurang baik yaitu 26 orang $(58,0 \%)$ dan kelompok kontrol pada kategori baik yaitu 32 orang $(71,1 \%)$ dengan ( $p$-value pada kasus 0,000 dan pada kontrol 0,004). Utilitation habit responden pada kelompok kasus berada pada kategori tidak ada yaitu 26 orang $(57,8 \%)$ dan kelompok kontrol pada kategori tidak ada 37 orang $(82,2 \%)$ dengan ( $p$-value pada kasus 0,006 dan kontrol 0,000). Kesimpulan dalam penelitian ini adalah variabel pengetahuan, sika dan budaya terdapat hubungan yang bermakna pada kelompok kasus dan kontrol.
\end{abstract}

Kata kunci: diare, perilaku penggunaan air sungai, pengetahuan 


\section{PENDAHULUAN}

Pada saat ini Indonesia sedang mengalami transisi epidemiologi dalam hal masalah kesehatan dimana kondisi penyakit menular yang belum dapat diatasi seluruhnya. Permasalahan penyakit menular diantaranya yang paling sering terjadi adalah diare. Diare merupakan suatu keadaan terjadinya perubahan frekuensi dan konsistensi tinja. Diare merupakan baung air besar dengan konsistensi lembek atau cair yang berupa air saja yang frekuensinya lebih dari biasanya (tiga kali atau lebih dalam sehari) (Depkes RI, 2000).

Dikutip dari Profil Kesehatan Indonesia (2015) penyakit diare merupakan penyakit endemis di Indonesia. Diare juga merupakan penyakit potensial Kejadian Luar Biasa (KLB) yang sering disertai dengan kematian. Pada tahun 2015 terjadi 18 kali KLB Diare yang tersebar di 11 provinsi, 18 kabupaten/kota, dengan jumlah penderita 1 . 213 orang dan kematian 30 orang (CFR $2,47 \%)$. Salah satu dari provinsi yang menjadi lokasi terjadinya KLB adalah Provinsi Kalimantan Selatan (Profil Kesehatan Indonesia, 2015).

Diare merupakan salah satu masalah kesehatan masyarakat yang paling menonjol di Kalimantan Selatan, walaupun untuk program pencegahan dan pemberantasan penyakit menular pun mengalami peningkatan pencapaian, namun hal ini tetap menjadi konsentrasi dalam rencana dan strategi. Berdasarkan rencana dan strategi Dinas Kesehatan Provinsi Kalimantan Selatan tahun 2016 -2021. Kasus diare di Provinsi Kalimantan Selatan yang tercatat di Fasilitas Kesehatan sebesar 51.416 dan yang dapat tertangani sebesar 31.314 dengan persentase sebesar 60,9 (Profil Kesehatan Kalimantan Selatan, 2015).

Dari 230 Puskesmas yang berada di Provinsi Kalimantan Selatan, hampir semua Puskesmas di Provinsi ini memiliki kasus diare. Salah satu Puskesmas yang memiliki kasus diare tertinggi di Provinsi ini adalah Puskesmas Pasayangan Martapura (Profil Kesehatan Kalimantan Selatan, 2015).
Berdasarkan penelitian sebelumnya yang dilakukan oleh Felicia (2003), terdapat hubungan antara faktor lingkungan yang meliputi sumber air minum $(p=0,001)$. Ini berarti sumber air sebagai pemenuhan kebutuhan fisilogis manusia merupakan salah satu hal yang berperan dalam terjadinya kejadian diare. Penggunaan sumber air yang dilakukan berulang kali, menentukan kebiasaan perilaku menggunakan air.

Kalimantan Selatan memiliki banyak sungai, sungai yang terdapat disana digunakan sebagai sumber air bersih dan banyak pemukiman yang berdiri di pinggir sungai. Selain itu sungai juga menunjang aktivitas masyarakat seperti MCK, perdagangan, jalur transportasi ataupun pariwisata. Sungai memiliki definisi sebagai tempat-tempat dan wadah-wadah serta jaringan pengaliran air mulai dari mata air sampai muara dengan dibatasi kanan dan kirinya serta sepanjang pengalirannya oleh garis sempadan (PP RI No 35 tahun 1991).

Seiring dengan adanya kemajuan pada teknologi masa kini, maka manusia difasilitasi untuk mendapatkan berbagai sumber air. Seperti ketersediaan air PDAM dan air minum juga adanya ketersediaan air minum air isi ulang yang dapat dicapai dengan mudah. Berdasarkan data yang telah disajikan sebelumnya dapat disimpulkan bahwa banyaknya penyakit diare setiap tahunnya cenderung menurun dan perbandingannya lebih kecil dari angka maksimal. Hal tersebut dikarenakan salah satunya pemahaman masyarakat tentang penggunaan air bersih dan sanitasi semakin meningkat dari tahun ke tahun. Observasi yang dilakukan pada lingkungan masyarakat yang bermukim padat daerah aliran sungai (DAS) di sekitar Martapura 2, sebagian besar masyarakat sudah memiliki kakus di rumahnya sendiri.

Sebagian masyarakat masih menggunakan air sungai untuk keperluan MCK (mandi, cuci, kakus). Untuk keperluan konsumsi masyarakat telah banyak menggunakan air PDAM dan air sumur walaupun tidak dipungkiri bahwa air sungai 
juga masih digunakan. Berdasarkan survei pendahuluan yang dilakukan pada tanggal 20-21 bulan Mei tahun 2017, terlihat bahwa masyarakat yang mengalami diare sebagian besar tinggal pada daerah aliran sungai Martapura. Berdasarkan survei pendahuluan diketahui bahwa sebagian besar masyarakat wilayah kerja Puskesmas Martapura 2 memiliki kebiasaan mencuci pakaian maupun peralatan dapur, buang air besar/kecil, mencuci kendaraan bermotor hingga konsumsi untuk air minum diambil dan dilakukan di sungai Martapura.

Hasil survey pendahuluan pada tanggal 20-21 bulan Mei tahun 2017 yang dilakukan menjelaskan bahwa sebagian besar masyarakat di wilayah aliran sungai Martapura masih melaksanakan berbagai macam aktivitas di sungai sehingga kemungkinan untuk terjadinya kontaminasi silang pada air sungai bisa saja terjadi. Perilaku masyarakat yang buruk tentang sanitasi terutama dalam hal penyediaan dan penggunaan air bersih dapat menurunkan derajat kesehatan masyarakat itu sendiri.

\section{METODE PENELITIAN}

Penelitian ini merupakan penelitian kuantitatif. Proses penggalian informasi diwujudkan dalam bentuk angka sebagai alat untuk menemukan keterangan mengenai apa yang diketahui (Notoadmojo, 2004). Pendekatan yang digunakan adalah case control/ kasus kontrol adalah studi analitik yang menganalisis hubungan kausa dengan menggunakan logika terbalik, yaiu menentukan penyakit (outcome) terlebih dahulu kemudian mengidentifikasi penyebab. Riwayat paparan dalam penelitian ini dapat dipelajari dari register medis atau berdasarkan wawancara dari responden penelitian (Kuntjojo, 2009).

Studi kasus kontrol dilakukan dengan mengindentifikasi kelompok kasus dan kelompok kontrol, kemudian secara retrospektif diteliti faktor risiko yang mungkin dapat menerangkan apakah kasus dan kontrol dapat terkena paparan atau tidak. Populasi Penelitian ini adalah seluruh penderita diare di wilayah kerja Puskesmas Martapura 2.

Sampel penelitian ini adalah masyarakat yang pernah mengalami penyakit diare dalam waktu 1 tahun terakhir (Februari 2017-Februari 2018) yang tercakup dalam wilayah kerja Puskesmas Pasayangan. Penentuan sampel menggunakan kriteria inklusi yaitu penderita diare yang tercatat dalam data Puskesmas Martapura 2 pada kurun waktu 1 tahun terakhir, penderita diare dengan alamat lengkap yang tercatat di Puskesmas Martapura 2, dan dapat menyetujui menjadi responden. Kriteria eksklusi yaitu penderita diare yang tercatat dalam data Puskesmas (selain Februari 2017- Februari 2018) Martapura 2, dan penderita diare dengan alamat diluar kelurahan Pasayangan.

Kriteria inklusi digunakan pada kelompok kasus diare sedangkan kriteria eksklusi digunakan pada kelompok kontrol. Menggunakan rumus lemeshow didapatkan hasil yaitu 43 orang, dengan memperkirakan adanya kemungkinan eror yang terjadi reponden digenapkan menjadi 45 responden penderita diare dan karena menggunakan case control denga menggunakan sampel minimal $1: 1$ maka kontrol yang ada adalah 45 responden yang tidak menderita diare jadi total sampel adalah 90 responden

Penelitian ini menggunakan data primer. Data primer merupakan data yang diperoleh langsung dari responden yang mnjadi sampel penelitian dengan menggunakan kuisioner. Data sekunder didapatkan dari jumlah kasus diare perbulan wilayah Puskesmas Martapura 2 tahun 2009 - 2013 dan 2014 dan jumlah kasus diare Perbulan wilayah Puskesmas Martapura 2 tahun 2014- 2016, Data laporan bulanan diare Puskesmas Martapura 2.

Data tersebut kemudian dianalisis menggunakan uji statistik uji Chi Square. Data yang dianalisis dengan uji Chi Square atau dengan tujuan mengetahui adanya hubungan pengetahuan, sikap dan budaya terhadap perilaku penggunaan air sungai. Nilai $\alpha$ pada uji signifikansi penelitian ini sebesar $5 \%$ atau 0,05 . 
Penarikan kesimpulan dari analisis adalah jika nilai signifikansi kurang dari 0,05 maka terdapat hubungan antara pengetahuan, sikap dan budaya terhadap perilaku penggunaan air sungai dan jika nilai signifikansi lebih dari 0,05, maka tidak terdapat hubungan antara pengetahuan, sikap dan budaya terhadap perilaku penggunaan air sungai. Dasar pengambilan keputusan adalah terbukti yang kemudian diolah dan dianalisis menggunakan computer. Kemudian disajikan melalui tabel berdasarkan hasil yang telah diperoleh (Morton, 2009).

\section{HASIL PENELITIAN}

\section{Gambaran Karakteristik Responden}

Karakteristik responden digunakan untuk mengetahui keragaman responden berdasarkan umur, pendidikan, pekerjaan, riwayat sakit diare, tempat tinggal dan penggunaan air sungai. Hasil penelitian pada Tabel 1. menjelaskan bahwa sebagian responden berada pada umur kurang dari 2035 tahun, yaitu sejumlah 25 responden $(55,6 \%)$. Menurut tingkat pendidikan, responden yang terkategori tidak sekolah yaitu 15 responden (33,33\%). Sebagian besar responden memiliki pekerjaan wiraswasta yaitu 18 orang $(40,0 \%)$. Untuk riwayat sakit diare sebagian responden memiliki riwayat 1-2 kali sejumlah 37 orang $(82,2 \%)$. Sedangkan berdasarkan data yang diperoleh sebagian responden memiliki tempat tinggal berjarak $0-2 \mathrm{~km}$ dari aliran sungai sejumlah 41 orang $(91,1 \%)$. Berdasarkan penggunaan air sungai oleh responden sejumlah 19 orang $(42,2 \%)$ hampir setengah dari total jumlah responden kelompok kasus diare yaitu 45 orang. Berdasarkan penelitian diperoleh hasil mengenai karakteristik responden pada kelompok kasus diare disajikan dalam Tabel 1. Selain mengambil sampel pada kelompok kasus diare, peneliti juga mengambil sampel pada kelompok kontrol. Kelompok kontrol pada sebuah penelitian berfungsi sebagai pembanding, dari sebuah kelompok perlakukan atau observasi. Kelompok kontrol dalam penelitian ini adalah kelompok yang tidak pernah menderita diare dan berada diluar kelurahan pasayangan serta berada wilayah kerja Puskesmas Martapura 2.

Tabel 1. Karakteristik Kelompok Kasus Diare

\begin{tabular}{|c|c|c|}
\hline Umur & Jumlah & $\%$ \\
\hline$<20-35$ th & 25 & 55,6 \\
\hline $36-50$ th & 15 & 33,3 \\
\hline$>50$ th & 5 & 11,1 \\
\hline Total & 45 & 100 \\
\hline Pendidikan & Jumlah & $\%$ \\
\hline Tidak Sekolah & 15 & 33,3 \\
\hline $\mathrm{SD}$ & 6 & 13,3 \\
\hline SMP & 9 & 20,0 \\
\hline SMA & 12 & 26,7 \\
\hline PT & 3 & 6,7 \\
\hline Total & 45 & 100 \\
\hline Pekerjaan & Jumlah & $\%$ \\
\hline PNS & 3 & 6,7 \\
\hline Pegawai Swasta & 1 & 2,2 \\
\hline Wiraswasta & 18 & 40,0 \\
\hline IRT & 8 & 17,8 \\
\hline Tidak Bekerja & 15 & 33,3 \\
\hline Total & 45 & 100 \\
\hline $\begin{array}{l}\text { Riwayat Sakit } \\
\text { Diare }\end{array}$ & Jumlah & $\%$ \\
\hline Tidak Pernah & 0 & 0 \\
\hline $1-2$ kali & 37 & 82,2 \\
\hline 3-5 kali & 7 & 15,6 \\
\hline$>5$ kali & 1 & 2,22 \\
\hline Total & 45 & 100 \\
\hline $\begin{array}{l}\text { Tempat Tinggal } \\
\text { (Aliran sungai) }\end{array}$ & Frekuensi & $\%$ \\
\hline $0-2 \mathrm{~km}$ & 41 & 91,1 \\
\hline$>2 \mathrm{~km}$ & 4 & 8,9 \\
\hline Total & 45 & 100 \\
\hline Penggunaan Air & Jumlah & $\%$ \\
\hline Menggunakan & 19 & 42,2 \\
\hline $\begin{array}{c}\text { Tidak } \\
\text { Menggunakan }\end{array}$ & 26 & 57,8 \\
\hline Total & 45 & 100 \\
\hline
\end{tabular}

Berdasarkan hasil penelitian yang disajikan pada Tabel 2. menjelaskan bahwa sebagian responden berada pada umur 36 - 
50 tahun, yaitu sejumlah 22 kelompok kasus diare $(48,9 \%)$.

Tabel 2. Karakteristik Kelompok Kontrol

\begin{tabular}{|c|c|c|}
\hline Umur & Jumlah & $\%$ \\
\hline$<20-35$ th & 13 & 28,9 \\
\hline $36-50$ th & 22 & 48,9 \\
\hline$>50$ th & 10 & 22,2 \\
\hline Total & 45 & 100 \\
\hline Pendidikan & Jumlah & $\%$ \\
\hline Tidak Sekolah & 6 & 13,3 \\
\hline SD & 9 & 20,0 \\
\hline SMP & 10 & 22,2 \\
\hline SMA & 16 & 35,6 \\
\hline PT & 4 & 8,9 \\
\hline Total & 45 & 100 \\
\hline Pekerjaan & Jumlah & $\%$ \\
\hline PNS & 1 & 2,2 \\
\hline Pegawai Swasta & 0 & 0 \\
\hline Wiraswasta & 19 & 42,2 \\
\hline IRT & 10 & 22,2 \\
\hline Tidak Bekerja & 15 & 33,3 \\
\hline Total & 45 & 100 \\
\hline Riwayat Sakit & Jumlah & $\%$ \\
\hline Tidak Pernah & 45 & 0 \\
\hline $1-2$ kali & 0 & 0 \\
\hline $3-5$ kali & 0 & 0 \\
\hline$>5$ kali & 0 & 0 \\
\hline Total & 45 & 100 \\
\hline Tempat Tinggal & Jumlah & $\%$ \\
\hline $0-2 \mathrm{~km}$ & 34 & 75,6 \\
\hline$>2 \mathrm{~km}$ & 11 & 24,4 \\
\hline Total & 45 & 100 \\
\hline Penggunaan Air & Jumlah & $\%$ \\
\hline Menggunakan & 13 & 28,9 \\
\hline $\begin{array}{c}\text { Tidak } \\
\text { Menggunakan }\end{array}$ & 32 & 71,1 \\
\hline Total & 45 & 100 \\
\hline
\end{tabular}

Menurut tingkat pendidikan, responden yang terkategori pada tingkat SMA yaitu sejumlah 16 kelompok kasus diare $(35,6 \%)$. Berdasarkan data yang diperoleh, sebagian besar kelompok kasus diare memiliki jenis pekerjaan wiraswasta yaitu 19 orang (42,2\%). Sebagian kelompok kasus diare memiliki tidak pernah memiliki riwayat sakit sejumlah 45 orang (100\%).
Sebagian kelompok kasus diare memiliki tempat tinggal berjarak $0-2 \mathrm{~km}$ dari aliran sungai sejumlah 41 orang $(91,1 \%)$ Berdasarkan penggunaan air sungai oleh kelompok kasus diare sejumlah 13 orang $(28,9 \%)$ atau sepertiga dari total jumlah yaitu 45 orang.

\section{Hubungan Tingkat Pengetahuan Responden Terhadap Perilaku Penggunaan Air Sungai}

Pengetahuan merupakan salah satu faktor yang mempunyai pengaruh dalam melakukan perilaku penggunaan air sungai. Berdasarkan data primer yang diperoleh melalui wawancara dengan menggunakan kuesioner, diperoleh hubungan tingkat pengetahuan responden terhadap perilaku penggunaan air sungai sebagai berikut :

Tabel 3. Hubungan Tingkat Pengetahuan Responden Terhadap Perilaku Penggunaan Air Sungai

\begin{tabular}{|c|c|c|c|}
\hline $\begin{array}{c}\text { Pengetahuan } \\
\text { Kasus } \\
\end{array}$ & Jumlah & $\%$ & p value \\
\hline Tahu & 20 & 44,4 & \multirow{3}{*}{0,000} \\
\hline Tidak Tahu & 25 & 55,6 & \\
\hline Total & 45 & 100 & \\
\hline $\begin{array}{c}\text { Pengetahuan } \\
\text { Kontrol }\end{array}$ & Jumlah & $\%$ & $p$ value \\
\hline Tahu & 35 & 77,8 & \multirow{3}{*}{0,000} \\
\hline Tidak Tahu & 10 & 22,2 & \\
\hline Total & 45 & 100 & \\
\hline
\end{tabular}

Hasil perhitungan Chi-Square Test pada Tabel 3. pada kelompok kasus dan kontrol dapat diketahui nilai $p=0,000$, artinya $p$ kurang dari 0,05 . Sehingga bisa disimpulkan bahwa ada hubungan antara pengetahuan pada kelompok kasus diare dan kontrol terhadap perilaku penggunaan air sungai. Sebagian besar responden pada kelompok kasus berada pada tidak tahu yaitu 25 orang $(55,6 \%)$ dan kelompok kontrol pada tahu yaitu 35 orang $(77,8 \%)$.

Rendahnya pengetahuan pada kelompok kasus yang sebagian besar hanya pada tingkat tidak sekolah/ tidak tamat SD dapat dipengaruhi oleh pendidikan rendah serta umur yang masih tergolong muda kurang dari 20- 35 tahun ini menyebabkan 
pengalaman yang dimiliki sedikit sedangkan pengetahuan yang dimiliki kelompok kontrol. Hasil penelitian pada kelompok kontrol menunujukkan bahwa pendidikan yang cukup dan umur yang tergolong cukup 36-50 tahun sehingga sebagian besar responden memiliki pengetahuan pada tahu.

\section{Hubungan Sikap Responden Terhadap Perilaku Penggunaan Air Sungai}

Sikap merupakan salah satu komponen penting yang berpengaruh dalam perilaku penggunaan air sungai karena tindakan yang dilakukan oleh seserang dapat tergambar dari sikap yang diperlihat oleh seseorang tersebut. Sikap menjadi sebuah hal yang penting. Berdasarkan data primer yang diperoleh melalui wawancara dengan menggunakan kuesioner, diperoleh hubungan sikap responden terhadap perilaku penggunaan air sungai sebagai berikut:

Tabel 4. Hubungan Sikap Responden Terhadap Perilaku Penggunaan Air Sungai

\begin{tabular}{|c|c|c|c|}
\hline $\begin{array}{l}\text { Sikap } \\
\text { Kasus }\end{array}$ & Jumlah & $\%$ & p value \\
\hline Baik & 18 & 40,0 & \multirow{3}{*}{0,000} \\
\hline Kurang Baik & 26 & 58,0 & \\
\hline Total & 45 & 100 & \\
\hline $\begin{array}{c}\text { Sikap } \\
\text { Kontrol }\end{array}$ & Jumlah & $\%$ & $p$ value \\
\hline Baik & 32 & 71,1 & \multirow{3}{*}{0,004} \\
\hline Kurang Baik & 13 & 28,9 & \\
\hline Total & 45 & 100 & \\
\hline
\end{tabular}

Hasil perhitungan Chi-Square Test pada Tabel 4. pada kelompok kasus dapat diketahui nilai $p=0,000$, artinya $p$ kurang dari 0,05. Sehingga bisa disimpulkan bahwa ada hubungan antara sikap pada kelompok kasus diare terhadap perilaku penggunaan air sungai. Sedangkan hasil perhitungan Chi-Square Test pada tabel 2 pada kelompok kontrol dapat diketahui bahwa nilai $p=$ 0,004 , artinya $p$ kurang dari 0,05 . Sehingga bisa disimpulkan bahwa ada hubungan antara pengetahuan pada kelompok kontrol diare terhadap perilaku penggunaan air sungai. Berdasarkan penelitian yang dilakukan sebagian responden pada kelompok kasus memiliki sikap kurang baik yaitu 26 orang $(58,0 \%)$ dan kelompok kontrol memilki sikap baik yaitu 32 orang $(71,1 \%)$.

Sikap kurang baik yang dimiliki oleh kelompok kasus dapat diperngaruhi oleh rendahnya pendidikan, umur yang muda serta letak tempat tinggal yang dekat dari daerah aliran sungai sehingga hal tersebut mendorong responden melakukan perilaku penggunaan air sungai. Sedangkan sikap baik yang dimilki kelompok kontrol didukung oleh pengetahuan yang baik, pendidikan yang tinggi dan umur yang cukup yang dimiliki oleh responden sehingga hal tersebut mendorong responden memiliki sikap yang baik dalam perilaku penggunaan air sungai yaitu sikap yang cenderung menjauhi perilaku seperti tidak melakukan konsumsi terhadap air sungai dan hanya menggunakan air sungai yang tidak terkait dengan konsumsi.

\section{Hubungan Budaya Responden Terhadap Perilaku Penggunaan Air Sungai}

Budaya merupakan hal yang tidak dapat dipisahkan dalam kehidupan di masyarakat karena budaya. Berdasarkan data primer yang diperoleh melalui wawancara dengan menggunakan kuesioner, diperoleh hubungan budaya responden terhadap perilaku penggunaan air sungai sebagai berikut:

Tabel 5. Hubungan Budaya Responden Terhadap Perilaku Penggunaan Air Sungai

\begin{tabular}{|c|c|c|c|}
\hline $\begin{array}{c}\text { Budaya } \\
\text { Kasus }\end{array}$ & Jumlah & $\%$ & p value \\
\hline Ada & 19 & 42,2 & \multirow{3}{*}{0,006} \\
\hline Tidak Ada & 26 & 57,8 & \\
\hline Total & 45 & 100 & \\
\hline $\begin{array}{l}\text { Budaya } \\
\text { Kontrol }\end{array}$ & Jumlah & $\%$ & p value \\
\hline Ada & 8 & 17,8 & \multirow{3}{*}{0,000} \\
\hline Tidak Ada & 37 & 82,2 & \\
\hline Total & 45 & 100 & \\
\hline
\end{tabular}


Hasil perhitungan Chi-Square Test pada tabel 5. pada kelompok kasus dapat diketahui nilai $p=0,006$, artinya $p$ kurang dari 0,01 . Sehingga bisa disimpulkan bahwa ada hubungan antara budaya pada kelompok kasus diare terhadap perilaku penggunaan air sungai. Sedangkan hasil perhitungan Chi-Square Test pada tabel 2 pada kelompok kontrol dapat diketahui bahwa nilai $p=$ 0,000 , artinya $p$ kurang dari 0,01 . Sehingga bisa disimpulkan bahwa ada hubungan antara budaya pada kelompok kontrol diare terhadap perilaku penggunaan air sungai. Sebagian besar responden pada kelompok kasus berada pada tidak ada yaitu 26 orang $(57,8 \%)$ dan kelompok kontrol pada kategori tidak ada yaitu 37 orang $(82,2 \%)$.

Keberadaan budaya dalam suatu kelompok masyarakat dipengaruhi oleh berbagai macam hal, yang terbesar adalah kondisi jaman yang mempengaruhi budaya tersebut bertahan dalam suatu tatanan masyarakat atau tidak. Pengaplikasian budaya berdasarkan kebiasaan yang ada tergantung pada individu itu sendiri.

\section{PEMBAHASAN}

\section{Gambaran Karakteristik Responden}

Pada hasil penelitian diperoleh data responden pada kelompok kasus diare yang mendominasi adalah pada kategori umur kurang dari 20 tahun - 35 tahun. Sedangkan pada kelompok konrol diare mayoritas responden berumur 36 tahun - 50 tahun. Hal ini sejalan dengan pernyataan Suraatmaja (2007) bahwa semakin muda umur seseorang, semakin tinggi kecenderungan terserang diare. Daya tahan tubuh yang rendah membuat tingginya angka kejadian diare.

Salah satu faktor yang mempengaruhi perilaku kesehatan adalah umur. Menurut Suryabudhi (2003) semakin lama hidup seseorang maka pengalaman hidupnya semakin banyak, pengetahuannya semakin luas, keahliannya semakin mendalam serta kearifannya semakin baik dalam pengambilan keputusan tindakannya. Semakin tua umur seseorang biasanya semakin banyak pengalaman yang dimiliki. Pengambilan keputusan yag didasari oleh pengalaman memiliki manfaat bagi pengetahuan praktis, karena dengan pengalaman yang dimiliknya, maka seseorang dapat memperkirakan sesuatu keadaan, serta dapat memperhitungkan untung-ruginya dan baik-buruknya akan keputusan yang dihasilkan.

Pada hasil penelitian diperoleh data respoden pada kelompok kasus diare sebagian besar responden terkategori berada pada tingkat tidak sekolah / tidak tamat SD. Sedangkan pada kelompok kontrol terkategori berada pada tingkat SMA/Sederajat. Jenjang pendidikan memegang peranan yang cukup penting dalam kesehatan masyarakat. Pendidikan seseorang yang tinggi memudahkan orang tersebut dalam penerimaan informasi, baik dari orang lain maupun media masa. Banyaknya informasi yang masuk akan membuat pengetahuan tentang penyakit diare semakin bertambah. Hal ini menggambarkan bahwa kelompok kasus diare banyak diderita oleh orang-orang yang memiliki pendidikan rendah yang memungkingkan kurangnya dalam penerimaan informasi yang diterima.

Menurut Johnnie (1993) pendidikan merupakan proses mendapatkan pengetahuan dan menggunakan pengetahuan tersebut untuk memahami aktivitas dan lingkungan sekitar. Pendidikan menengah yang diperkirakan sudah cukup baik dalam menggunakan pengetahuan baik itu terkait diare yang akan berdampak pada perilaku yang akan dilakukannya juga. Didukung pula oleh Green (2005), yang menyatakan tingkat pendidikan seseorang dapat mempengaruhi pola pikir seseorang untuk menerima informasi dan edukasi.

Pada hasil penelitian diperoleh data respoden pada kelompok kasus diare dan kontrol sebagian besar didominasi pekerjaan yaitu wiraswasta. Pada umumnya responden memilih profesi wiraswasta seperti pedagang, pengusaha, guru ngaji, tukang ojek dan lainnya. Wiraswata merupakan pekerjaan yang termasuk dalam sektor 
informal. Pada umumnya pekerja informal ini berdiri sendiri atau membentuk kelompok-kelompok kecil, berpindahpindah dan bekerja dengan berbagai keterbatasan yang ada seperti modal yang kecil, penguasaan teknologi yang terbatas dan rendahnya pengetahuan termasuk pengetahuan dibidang kesehatan. Rendahnya pengetahuan pekerja informal akan kesehatan dan keselamatan kerja ini menyebabkan mereka sangat berisiko untuk terkena penyakit (Kemenkes, 2015).

Pekerjaan merupakan kegiatan yang dilakukan seseorang untuk menghasilkan sesuatu serta memenuhi kebutuhannya. Manusia memiliki kebutuhan pokok. Lingkungan pekerjaan menjadikan seseorang memperoleh pengalaman dan pengetahuan baik secara langsung maupun tidak langsung. Pengalaman dan pengetahuan yang secara tidak langsung diperoleh melalui pekerjaan secara tidak langsung memberikan dampak terhadap perilaku kesehatan yang dilakukannya. Seperti guru ngaji yang menyatakan kebersihan sebagian dari iman maka sudah pasti dia menerapkan cuci tangan dan mandi teratur dalam rangka menjaga kebersihan dirinya (Suhartini, 2007).

Pada hasil penelitian diperoleh data pada kelompok kasus diare sebagian besar responden memiliki riwayat 1-2 kali. Riwayat sakit tersebut diderita dalam kurun waktu setahun terakhir yaitu februari 20172018 sesuai data register bulanan. Riwayat sakit dapat dipengaruhi perilaku yang dilakukan responden. Pada kelompok kontrol tidak terdapat responden yang menderita diare dalam kurun waktu setahun terakhir.

Hal ini sejalan dengan penelitian yang dilakukan oleh Anjar (2009) menyebutkan bahwa riwayat penyakit yang terdapat dalam keluarga dapat mendorong seseorang untuk berperilaku sehat dan melakukan deteksi dini pada penyakit tersebut. Jika seseorang pernah mengalami diare seharusnya dia mampu melindungi dirinya lebih baik dari seseorang yang pernah mengalami diare. Hal ini disebabkan karena seseorang yang pernah diare dianggap mampu menghindari faktor faktor risiko yang dapat menyebabkan diare seperti perilaku penggunaan air sungai.

Pada hasil penelitian diperoleh data pada kelompok kasus diare dan kontrol menunjukkan responden bertempat tinggal yaitu $0-2 \mathrm{Km}$ dari aliran sungai. Tempat tinggal berkaitan dengan resources (sumber daya) yang ada dalam salah satu komponen Teori WHO hingga hal ini berpengaruh terhadap perilaku kesehatan yang menyebabkan kesakitan dalam penilitian ini yaitu diare. Tempat tinggal merupakan wujud bangunan rumah, tempat berteduh, atau struktur lainnya yang digunakan sebagai tempat untuk tinggal. Didominasinya tempat tinggal yang dekat dengan sumber air tersebut diasumsikan dapat menjadi salah satu faktor masih terdapatnya perilaku penggunaan air sungai oleh responden.

Salah satu faktor yang menentukan derajat kesehatan masyarakat adalah faktor lingkungan dalam hal ini jarak tempat tinggal termasuk juga dalam kemudahan akses pada lingkungan fisik yaitu jarak yang dekat dengan pemukiman (Blum, 1974)

\section{Hubungan Pengetahuan Terhadap Perilaku Penggunaan Air Sungai}

Pada penelitian ini diperoleh hasil terdapat hubungan yang bermakna pada kelompok kasus diare terhadap perilaku penggunaan air sungai. Pengetahuan salah satunya diperoleh dari pendidikan, dari segi pendidikan kelompok kasus diare memiliki pendidikan yang rendah. Maka peneliti berasumsi pengetahuan rendah dimiliki kelompok kasus diare, didukung pula pendidikan rendah selain itu informasi bisa didapatkan melalui pengalaman yang dimiliki responden seperti pekerjaan. Pengalaman yang dimaksudkan adalah pengalaman individu untuk dapat melakukan perilaku yang sama atau berulang-ulang sehingga seseorang dapat memiliki keyakinan pada perilaku penggunaan air sungai. 
Pada kelompok kontrol diperoleh hasil terdapat hubungan yang bermakna terhadap perilaku penggunaan air sungai. Dari segi pendidikan maka control yaitu responden yang tidak menderita diare memiliki tingkat pendidikan cukup baik dengan sebagian besar berada pada tingkat SMA. Semakin tinggi tingkat pendidikan seseorang maka semakin banyak pengalaman, sehingga untuk cara berfikirnya akan semakin berbeda, bersikap, dan berperilaku dibandingkan dengan individu yang memiliki tingkat pendidikan lebih rendah. Seseorang yang memiliki tingkat pendidikan akan memandang suatu permasalahan jauh lebih logis dan rasional.

Hasil penelitian ini sejalan dengan penelitian yang dilakukan oleh Rudi (2008) tentang hubungan pengetahuan dan sikap ibu dengan kejadiaan diare pada batita di Desa Sawojajar, yang menyatakan bahwa terdapat hubungan yang signifikan antara pengetahuan ibu dengan tingkat kejadian diare pada anaknya. Dan penelitian oleh Dofi (2013) tentang hubungan antara pengetahuan dengan kejadian diare pada anak di kelurahan Pabbundukang, kecamatan Pangkajene, kabupaten Pangkep juga menyatakan adanya hubungan antara pengetahuan terhadap kejadian diare.

Pemikiran dan perasaan seseorang digambarkan melalui pengetahuan dan sikap. Pengetahuan adalah hasil "tahu" dan terjadi setelah orang tersebut melakukan pengamatan dan penginderaan terhadap suatu obyek tertentu. Penginderaan terjadi melalui panca indera manusia yaitu: indera penglihatan, pendengaran, penciuman, rasa dan raba. Sebagian besar pengetahuan manusia diperoleh melalui mata dan telinga (Notoadmodjo, 2003). Pendidikan tinggi mengajarkan orang untuk berpikir lebih logis dan rasional untuk melihat sebuah isu dari berbagai sisi, sehingga dapat melakukan analisis dan memecahkan permasalahan tertentu. Selain itu, pendidikan tinggi memperbaiki keterampilan kognitif yang diperlukan untuk dapat terus belajar di luar sekolah (Laflamme, 2004).

\section{Hubungan Sikap Terhadap Perilaku Penggunaan Air Sungai}

Pada penelitian ini diperoleh hasil terdapat hubungan yang bermakna pada kelompok kasus diare dan kontrol pada sikap responden terhadap perilaku penggunaan air sungai. Penelitian ini sejalan dengan penelitian Ginting (2011) tentang hubungan antara kejadian diare pada balita dengan sikap dan pengetahuan ibu tentang perilaku hidup bersih dan sehat di Puskesmas Siantan Hulu Pontianak Kalimantan Barat, menyatakan adanya hubungan yang bermakna antara sikap dengan kejadian diare pada balita.

Newcomb dalam Notoatmodjo (2005) menyatakan sikap adalah kesiapan atau kesediaan untuk bertindak. Fungsi sikap belum merupakan tindakan (reaksi terbuka) atau aktivitas, akan tetapi merupakan predisposisi perilaku (tindakan) atau reaksi terbuka. Sehingga sikap menjadi gambaran sebelum terjadi tindakan.

Sikap terdiri dari sikap positif dan negatif. Sikap positif akan membawa sesseorang dalam melakukan perilaku yang baik khususnya yang berhubungan dengan kesehatan. Sedangkan sikap negatif akan membawa seseorang dalam perilaku yang kurang baik hingga berdampak buruk terhadap kesehatan (Nasikin, 2007).

Seharusnya sikap yang baik mendorong seseorang untuk menjauhi perilaku yang negatif yaitu masih menggunaan air sungai, ini berarti sikap yang ada belum sampai pada tahap melakukan tindakan yang baik pula. Masih besarnya kecenderungan responden menggunakan air sungai dapat menjadi salah satu penyebab terjadinya kesakitan (diare) pada responden. Sikap berpengaruh terhadap perilaku, yaitu bahwa sikap yang diyakini oleh seseorang menentukan apa yang akan dilakukan olehnya. Semakin khusus sikap seseorang yang kita ukur dan semakin khusus pula untuk kita mengidentifikasi perilaku terkait, maka semakin besar kemungkinan kita dapat memperoleh 
hubungan yang signifikan diantara keduanya.

Sikap jika dilihat dari sudut pandang evaluasi. Sikap dapat diartikan sebagai suatu sistem evaluasi positif atau negatif, yakni suatu kecenderungan untuk menyetujui atau menolak. Sikap positif terbentuk apabila rangsangan atau efek yang datang pada seseorang memberikan pengalaman atau kesan yang menyenangkan (Sudaryat, 2010). Sedangkan sikap negatif akan timbul bila rangsangan yang datang memberi pengalaman atau kesan yang tidak menyenangkan. Perbedaan sikap tersebut berhubungan dengan derajat kesukaan atau ketidaksukaan seseorang terhadap suatu obyek, dengan kata lain sikap berkaitan dengan kesiapan individu untuk bereaksi terhadap obyek tertentu berdasarkan konsep penilaian positif-negatif.

Sikap merupakan pernyatan evaluatif baik yang menguntungkan atau tidak. Sikap pada responden kelompok kasus dan kontrol menggambarkan bahwa karakteristik responden mendorong hingga sikap memilki hubungan yang bermakna terhadap peilaku penggunaan air sungai. Sikap pada kelompok kasus cenderung berada pada hal positif sedangkan pada kelompok kontrol cenderung berada pada hal negatif yag mendorong perilaku penggunaan air sungai (Aditya, 2008).

\section{Hubungan Budaya Terhadap Perilaku Penggunaan Air Sungai}

Pada penelitian ini diperoleh hasil terdapat hubungan yang bermakna antara habit terhadap perilaku penggunaan air sungai pada kelompok kasus diare dan kelompok kontrol. Ini berarti kebudayaan memberikan peranan erat terkait dengan perilaku penggunaan air sungai yang dilakukan oleh responden (Solahudin, 2008).

Budaya merupakan suatu tatanan yang meliputi pengetahuan, keyakinan, seni, moral, adat-istiadat serta kemampuan dan kebiasaan lain yang dimiliki manusia sebagai bagian masyarakat (Hawkins, 2012). Habit ditemukan pada kelompok kasus penderita diare yaitu kepercayaan mencuci tangan, kebiasaan mandi di sungai bersama saat pagi hari, kebiasaan mencuci peralatan masak/alat dapur menggunakan air sungai, kebiasaan mencuci pakaian di sungai, dan kebiasaan memasak air sungai untuk di konsumsi.

Budaya adalah suatu pandangan hidup dari sekelompok orang dalam bentuk perilaku, kepercayaan, nilai, dan simbolsimbol yang mereka terima tanpa sadar yang semuanya diwariskan melalui proses komunikasi dari satu generasi ke generasi berikutnya. Sehingga kebudayaan yang ada didapatkan dari warisan nilai-nilai yang ada sejak dulu. Budaya merupakan aspek yang sangat erat kaitannya dengan kehidapan di masyarakat. Budaya merupakan aspek yang susah dihilangkan, namun dapat berubah secara perlahan dan bertahap mengikuti perkembangan zaman (Adisasmito, 2007).

Kebiasaan yang ditanamkan sejak kecil akan berpengaruh terhadap kebiasaan pada seseorang ketika ia dewasa. Misalnya saja, ketika manusia terbiasa menggunakan air sungai sejak kecil, akan sulit diubah kebiasaan makannya setelah dewasa. Budaya dalam penelitian ini terkait dengan masih ditemukannya masyarakat yang mandi di sungai, mencuci peralatan masak dengan air sungai, serta masih ada masyarakat yang menggunakan air sungai untuk minum (Jogiyanto, 2007).

\section{SIMPULAN}

Karakteristik responden pada kelompok kasus sebagian besar berada pada rentang umur kurang dari 20-35 tahun, terkategori pada tingkat pendidkan rendah (tidak sekolah/ tidak tamat SD), memilki pekerjaan wiraswasta, tempat tinggal berjarak 0-2 km dari aliran air sungai dan memiliki riwayat 1-2 kali diare dan kurun waktu setahun terakhir. Sedangkan karakteristik responden pada kelompok kontrol sebagian besar berada pada rentang umur 26-50 terkategori pendidikan pada tingkat SMA, memiliki pekerjaan wiraswasta, tempat tinggal berjarak $0-2 \mathrm{~km}$ 
dari aliran air sungai dan tidak memiliki riwayat sakit diare dalam kurun waktu setahun terakhir. Terdapat hubungan antara pengetahuan, sikap dan budaya terhadap perilaku penggunaan air sungai pada kelompok kasus diare dan kontrol.

Bagi responden kelompok kasus diare dan kontrol bukan penderita diare yaitu melakukan pengalihan penggunaan air sungai dengan peralatan yang tidak digunakan untuk konsumsi seperti mencuci kendaraan, Menimbulkan kesadaran pada keluarga akan pentingnya pengunaan air bersih dengan pengolahan yang baik untuk menghindari berbagai dampak buruk yang bisa ditimbulkan, Lebih banyak menambah informasi mengenai diare dan penanggulangannya dalam rangka pencegahan kejadian diare berikutnya, Sebaiknya membiasakan untuk tidak menggunakan sumber air bersih yang belum melalui proses pengolahan ataupun mutunya terjamin baik secara kualitas dan kuantitas dan hanya menggunakan air yang sudah mengalami pengolahan dengan baik seperti air PDAM atau air galon untuk melakukan kegiatan sehari-hari yang terkait konsumsi seperti sikat gigi, mencuci peralatan memasak, dan konsumsi air minum dan memasak. Kepada instansi kesehatan yatu lebih menggiatkan promosi kesehatan mengenai penggunaan sumber air yang layak untuk dikonsumsi karena masih kuatnya pengaruh budaya di masyarakat dan menggandeng para tokoh masyarakat terkait untuk lebih gencar mempromosikan meminimalkan penggunaan air sungai

\section{DAFTAR PUSTAKA}

Adisasmito W. 2007. Faktor Risiko Diare Pada Bayi Dan Balita Di Indonesia: Systematic Review Penelitian Akademik Bidang Kesehatan Masyarakat. Fakultas Kesehatan Masyarakat. Universitas Indonesia, Depok 16424, Indonesia. Makara, Kesehatan, Vol. 11, No. 1, Juni 2007: 1-10.
Aditya, D.P. 2008. Perilaku Menggunakan Air Sungai Ditinjau Dari Persepsi Terhadap Kesehatan. Skripsi. Universitas Katolik Soegijapranata.

Anjar, P.W. 2009. Hubungan Antara Faktor Lingkungan dan Faktor Sosiodemografi dengan Kejadian Diare Pada Balita Di Desa Blimbing Kecamatan Sambirejo Kabupaten Sragen Tahun 2009. Skripsi. Universitas Muhammadiyah Surakarta.

Blum, Hendrik L. 1974. Planning for Health, Development and Aplication of Social Changes Theory. New York: Human Sciences Press

Depkes RI. 2010. Buku Pedoman Pengendalian Penyakit Diare. Jakarta: Depkes RI.

Departemen Kesehatan RI. 2002. Rencana Strategi Direktorat Jenderal Pemberantasan Penyakit Menular dan Penyehatan Lingkungan, 20012004. Jakarta: Depkes RI

Depkes RI. 2003. Pedoman Pemberantasan Diare, Direktorat Jenderal Bina Kesehatan Masyarakat. Jakarta: Depkes RI

Depkes RI. 2005. Pedoman Pemberantasan Penyakit Diare Edisi 4. Jakarta: Depkes RI.

Dinas Kesehatan Provinsi Kalimantan Timur, 2016. Profil Kesehatan Provinsi Kalimantan Timur 2015. Banjar: Dinas Kesehatan Provinsi Kalimantan Timur

Dinkeskab Banjar. 2014. Profil Kesehatan Kabupaten Banjar. Martapura: Dinkes Kabupaten Banjar.

Dofi, P. 2013. Hubungan Antara Penggunaan Air Sungai dan Kejadian Diare pada Keluarga yang Bermukim Di Sekitar Sungai Kapuas Kelurahan Siantan Hilir Pontianak. Naskah Publikasi. Universitas Tanjung Pura.

Feliciana, V.S.C.W. 2003. Hubungan Sarana Air Bersih, Jamban, dan Sarana Pebuangan Air Limbah dengan Kejadian Diare Pada Balita di 
Kabupaten Tangerang Tahun 2003. Skripsi. Universitas Indonesia.

Ginting. 2011. Hubungan Antara Kejadian Diare pada batita dengan Sikap dan Pengetahuan Ibu Tentang PHBS Di Puskesmas Siantan Hulu Pontianak Kalimantan Barat. Jurnal Pendidikan Bidan ISSN: 2089- 2225.

Green, L. 1980. Health Education Planning A Diagnostic Approach. Baltimore. The John Hopkins University: Mayfield Publishing Co

Green L, Kreuter M. 2005. Health Promotion Planning: An Educational and Ecological Approach. Mountain View.CA : Mayfield.

Hawkins, P. 2012. Creating a Coaching Habit. New York: Bell and Bain Ltd.

Jogiyanto, 2007. Sistem Informasi Keperilakuan Edisi Revisi. Yogyakarta: Andi Offset

Johnnie, P. 1993. Formal Education: A Paradigm of Human Resource Development. The International Journal of Educational Management.

Kementrian Kesehatan. 2014. Profil Kesehatan Indonesia. Jakarta: Kemenkes

Kepmenkes RI

Nomor 1216/Menkes/SK/X1/2001 tentang Pedoman Pemberantasan Penyakit Diare. Jakarta: Depkes RI.

Kuntjojo. 2009. Metodelogi Penelitian. Kediri: Universitas Nusantara PGRI.

Laflamme L, K. Engström, J. Möller, J. Hallquist. 2004. Is perceived failure in schools performance a trigger of physical injury? A case-crossover study of children in Stockholm County. Journal of Epidemiology and Community Health, no. 58, pp. 407-411.

Morton, R. 2009. Panduan Studi Epidemiologi dan Biostatistik. Jakarta: EGC.
Nasikin M. 2007. Pemanfaatan Sungai Jjar Sebagai Sarana Mandi Cuci dan Kakus (MCK); Studi Kasus Terhadap Perilaku Masyarakat di Kelurahan Singorejo Kecamatan Demak Kabupaten Demak. Thesis. Universitas Negeri Semarang

Notoatmodjo, S. 1997. Ilmu Kesehatan Masyarakat Prinsip-Prinsip Dasar. Jakarta: Rineka Cipta.

Notoatmodjo, S. 2003. Pendidikan dan Perilaku Kesehatan. Jakarta: Rineka Cipta.

Notoatmodjo, S. 2010. Metodologi Penelitian Kesehatan. Jakarta: Rineka Cipta

PPRI 35 Tahun 1991 Tentang Sungai. Jakarta: Departemen Pekerjaan Umum

Solahudin, E. 2008. Buku Kiat Jitu Mendapatkan Pekerjaan Idaman. Jakarta: Escaeva

Sudaryat, S. 2010. Gastroenterologi Anak Lab/SMF Ilmu Kesehatan Anak Fakultas UNUD. Bali: Universitas Udayana.

Suhartin. 2007. Perbedaan Sikap Tentang Perilaku Seks Pranikah Antara Remajja Laki-Laki dan Perempuan di SMAN 1 Tenggarang, Bondowoso. DIV Kebidanan UNS. KTI.

Sulthon, R.A.A. 2013. Faktor Penyebab Masyarakat Melakukan Mandi Cuci Kakus (MCK) Di Sungai. Skripsi. Universitas Jember.

Suraatmaja S. 2007. Kapita selektagastroenterologi. Jakarta: Sagung Seto.

Suryabudhi, M. 2003. Cara Merawat Bayi dan Anak-anak. Bandung: Alfabeta.

WHO. 1992. Reading on Diarrhoe. Geneva: World Health Organization Digital Library 